\title{
Society Report
}

Since the Annals of the College contain no record of an approach having been made to the College for this purpose, and since Palmer may have been relying on hearsay, I am wondering what foundation there is in fact for this story.

I should be interested to hear from any of your readers if they have any other evidence to produce in its support.

Yours faithfully, E. G. DODDS

\section{DR. SAMUEL JOHNSON'S AGGOUNT OF A SGHIZO- PHRENIG ILLNESS IN RASSELAS: A POSTSGRIPT}

As further proof of Samuel Johnson's influence on nineteenth-century psychiatry (Med. Hist., 1962, 6, 162-8) chapter thirteen of Oliver Wendell Holmes's A Mortal Antipathy (1885) deserves attention. The physician Dr. Butts, who is interested equally in the mind and the body, reads a paper for the improvement of all young people who are thinking of pursuing the study of medicine. In this paper he recommends Rasselas to his audience and cites a lengthy passage from the astronomer episode. The subject is introduced thus:

But if you ask me what reading I would commend to the medical student of a philosophical habit of mind, you may be surprised to hear me say it would be certain passages in Rasselas. They are the ones where the astronomer gives an account to Imlac of his management of the elements. ... Let me read you a few sentences from this story. . . .

Begin your medical studies, then, by reading the fortieth and the following four chapters of Rasselas. Your first lesson will teach you modesty and caution in the pursuit of the most deceptive of all practical branches of knowledge. Faith will come later. ...

KATHLEEN M. GRANGE

\section{Society Report}

\section{FAGULTY OF THE HISTORY OF MEDIGINE AND PHARMAGY}

The Faculty's Third Annual Report was presented to the Annual General Meeting held at Apothecaries' Hall on Wednesday, 18 April 1962. Dr. W. S. C. Copeman, the Chairman, said that it was a record of gratifying progress, with increasing membership, a number of successful meetings, and an extension of the Faculty's influence in the medical schools. Enrolments for the Second British Congress on the History of Medicine and Pharmacy held in September 196I showed a fifty per cent increase on those for the first congress. The congress theme-Chemistry in the Service of Medicine-had stimulated a number of thoughtful and informative papers from the distinguished contributors and these would shortly be available in volume form. The Congress Dinner given at Apothecaries' Hall had been graced by the presence of the President of The Royal Society, Sir Howard Florey, as guest of honour, and Sir Alexander Todd (now Lord Todd), the President of The Chemical Society (which 